\title{
Differential roles of Bcl2L12 and its short variant in breast cancer lymph node metastasis
}

\author{
SHANG-TAO CHIEN ${ }^{1,2}$, TZU-FENG YANG ${ }^{3,4}$, MING-CHANG YANG ${ }^{3,5}$, CHING-MEI HSU ${ }^{3}$, \\ YI-REN HONG ${ }^{3,6,7}$ and TAI-MIN LEE ${ }^{1}$ \\ ${ }^{1}$ Department of Pathology, Kaohsiung Armed Forces General Hospital; ${ }^{2}$ Department of Medical Laboratory Sciences \\ and Biotechnology, Fooyin University; ${ }^{3}$ Department of Biological Sciences, National Sun Yat-Sen University; \\ ${ }^{4}$ Department of Psychiatry and ${ }^{5}$ Laboratory of Medical Research, Kaohsiung Armed Forces General Hospital; \\ ${ }^{6}$ Department of Biochemistry, Faculty of Medicine, College of Medicine, Kaohsiung Medical University; \\ ${ }^{7}$ Graduate Institute of Medicine, Kaohsiung Medical University, Kaohsiung, Taiwan, R.O.C.
}

Received February 12, 2015; Accepted May 25, 2015

DOI: 10.3892/or.2015.4071

\begin{abstract}
Bcl2L12 plays a role in post-mitochondrial apoptosis through multiple mechanisms involving p53, $\alpha \mathrm{B}$-crystallin, caspase-3 and -7 in glioblastoma. Bcl2L12 is reported to be a good prognostic marker in breast cancer and correlated with ER and $\mathrm{Bcl} 2$ expression status. However, the mechanisms by which Bc12L12 regulates apoptosis in breast cancer (BCa) remain unknown. Recent studies have shown that Bcl2L12 expression is a useful biomarker in other types of cancer. Thus, we examined whether Bcl2L12 and Bcl2L12A mRNA were associated with breast cancer progression or a specific subtype. In total, 106 paraffin-embedded, different stage breast cancer specimens were prepared and quantified for $\mathrm{Bcl} 2 \mathrm{~L} 12$ and $\mathrm{Bcl} 2 \mathrm{~L} 12 \mathrm{~A}$ expression by PCR. The correlation between Bcl2L12 and Bcl2L12A mRNA levels and clinicopathological characteristics was statistically analyzed. The results showed that $\mathrm{Bcl} 2 \mathrm{~L} 12$ and $\mathrm{Bcl} 2 \mathrm{~L} 12 \mathrm{~A}$ mRNA expression was not significantly different across the different stage, grade and TNM classification groups $(\mathrm{P}>0.005)$. Using linear regression, Bcl2L12 mRNA was associated with Bcl2L12A mRNA, grade 3 tumor and the triple-negative breast cancer (TNBC) subtype. In non-TNBC specimens, Bcl2L12 mRNA was only correlated with Bcl2L12A mRNA. Bcl2L12A mRNA was positively associated with Bcl2L12 mRNA and the number of lymph node metastases, but negatively correlated with staging in the non-TNBC group. Specifically, Bcl2L12, but not Bcl2L12A, mRNA was significantly higher in TNBC and grade 3 tumors, respectively. In non-TNBC, Bcl2L12A mRNA was significantly highly expressed in tumors with
\end{abstract}

Correspondence to: Dr Shang-Tao Chien, Department of Pathology, Kaohsiung Armed Forces General Hospital, 2 Zhongzheng First Road, Lingya, Kaohsiung 80284, Taiwan, R.O.C.

E-mail: chienstk1@gmail.com

Key words: Bc12L12, Bcl2L12A, breast cancer, biomarker, triple negative breast cancer, paraffin-embedded tissues $\geq 12$ metastatic lymph nodes. Bcl2L12 and its variant mRNA were highly expressed in carcinoma in situ (CIS) samples. In addition, they were estimated to be correlated with the total sample and non-TNBC, but not the TNBC group. In summary, a high Bcl2L12 mRNA expression was associated with the high-grade $\mathrm{BCa}$ and TNBC subtype. In addition, the interplay between $\mathrm{Bcl} 2 \mathrm{~L} 12$ and its variant may be associated with high lymph node metastasis in non-TNBC tumors.

\section{Introduction}

Breast cancer $(\mathrm{BCa})$ is the leading cause of cancer-related mortality in women worldwide (1). The incidence of $\mathrm{BCa}$ in Taiwan has increased from 6.23/100,000 in 1970 to 23.76 in 2000 . In a 2005 report, breast cancer was the second most frequent cancer in women with an incident rate of $42.3 / 100,000$ (2). Cases in men are extremely rare and the ratio of males to females is $0.3: 100$. The Bureau of Health Promotion Data from 1998 to 2002 indicate that 5-year survival for all stages was $78.37 \%$. The 5- and 10-year survival rates were 98 and $95 \%$ for stage $0 ; 96$ and $89 \%$ for stage I; 90 and $82 \%$ for stage II; 65 and $53 \%$ for stage III; and 22 and $10 \%$ for stage IV (3). Triple-negative breast cancer (TNBC) accounts for $15-25 \%$ of the breast cancer cases. This subtype of $\mathrm{BCa}$ refers to any type of breast cancer that does not express the genes for estrogen (ER) and progesterone (PR) receptors, and Her2/neu (4). It is thought to be more aggressive and to respond poorly to hormone therapy, and is more difficult to treat since there is no receptor target to be antagonized. The risk of relapse in TNBC is also much higher for the first 3-5 years.

The Bcl2-like 12 (Bcl2L12) gene was identified and cloned by Scorilas et al (5) in 2001, and is a proline-rich (PxxP) protein and a newly identified member of the $\mathrm{Bcl} 2$ family, containing a highly conserved $\mathrm{BH} 2$ domain, a $\mathrm{BH} 3$-like motif and a proline-rich region. Currently, two splicing variants of the Bcl2L12 gene are known: one consisting of seven coding exons and producing a 334-amino acid protein with a molecular mass of $36.8 \mathrm{kDa}$, and another resulting from alternative splicing, leading to a protein of 176 amino acids, a splice variant known as Bcl2L12A which lacks exon 3 (143 bp) (5). 
Expression of the full-length mRNA transcript has been observed in many tissues, including breast, thymus, prostate, fetal liver, colon, placenta, pancreas, small intestine, spinal cord, kidney and bone marrow, whereas Bcl2L12A is mainly expressed in fetal liver, spinal cord and skeletal muscle (5). Bcl2L12 and Bcl2L12A are localized within the nucleus (6). The biological role of Bcl2L12 is not yet completely understood and remains paradoxical. In previous studies, Bcl2L12 and Bcl2L12A exhibited pro-apoptotic activity in BCa and gastric cancer (7-9). A 3-fold increase of Bcl2L12 levels was demonstrated in non-cancerous compared to cancerous stomach tissues (9). In $\mathrm{BCa}$, the two proteins are highly expressed in normal breast tissue, and Bcl2L12 has been identified as a favorable prognostic marker. Knockdown of its expression leads to cisplatin-resistance in the MDA-MB-231 $\mathrm{BCa}$ cell line (7). In nasopharyngeal cancer, th eBcl2L12 expression status was also found to be positively associated with distant metastases and to be an unfavorable and independent prognostic indicator of short-term relapse. Bcl2L12 mRNA expression may thus constitute a novel biomarker for the prediction of short-term relapse in nasopharyngeal carcinoma. By contrast, Bcl2L12 and Bcl2L12A are ubiquitously overexpressed in primary human GBMs and may be associated with resistance to chemotherapeutic agent-induced apoptosis, which is an important hallmark of this disease (10). Furthermore, Bcl2L12 plays an anti-apoptotic role in GBM and blocks post-mitochondrial apoptotic signaling by inhibiting effectors caspase-3 and -7 (11-13). Besides that, Bcl2L12 attenuates endogenous p53-directed transcriptomic changes after genotoxic stress and inhibits p53-dependent DNA damageinduced apoptosis (10). The anti-apoptotic role of Bcl2L12 and Bcl2L12A was found to be regulated by GSK3 $\beta$ in glioblastoma and was inhibited by $\mathrm{LiCl}$ (14). ER $\beta 5$ was observed to interact with Bc12L12 in a novel estrogen-independent molecular pathway that promotes cisplatin and/or doxorubicin-induced in vitro apoptosis of the MCF-7 and MDA-MD-231 BCa cell lines (15). Taken together, the roles of $\mathrm{Bcl} 2 \mathrm{~L} 12$ and its short variant in $\mathrm{BCa}$ remain largely unknown and contradictory. Moreover, it is also unclear whether Bcl2L12 and Bcl2L12A mRNA can be used as biomarkers for Bca progression and/or a subtype of BCa. Therefore, in this study we screened and analyzed the expression of $\mathrm{Bcl} 212$ and Bcl2L12A mRNA in clinical specimens to address these issues.

\section{Materials and methods}

Tissue collection. A total of 106 paraffin-embedded BCa tissues and 1 flesh tumor tissue were collected with the permission of the Institutional Review Board of Kaohsiung Armed Forces General Hospital in 2013. The expression profile of Bcl2L12 and Bcl2L12A was assessed and analyzed to determine whether they were correlated. The clinicopathological characteristics of these tumors are shown in Table I. There were $102(96.23 \%)$ invasive and $4(3.77 \%)$ non-invasive tumors. The invasive tumor group included ductal $(n=89,87.25 \%)$, lobular $(\mathrm{n}=4,3.92 \%)$, papillary $(\mathrm{n}=1,0.98 \%)$ carcinomas, medullary carcinomas, atypical $(\mathrm{n}=1,0.98 \%)$ and mucinous adenocarcinoma $(n=7,6.86 \%)$. The non-invasive tumors included ductal carcinoma in situ (CIS) $(\mathrm{n}=2,50.0 \%)$ and intraductal papillary carcinoma $(n=2,50.0 \%)$. Histological grades were classified
Table I. Clinicopathological characteristics of BCa specimens.

\begin{tabular}{lrr} 
Clinical diagnostic BCa type & & Total \\
\hline Invasive tumors & 102 & $106^{\mathrm{a}}$ \\
Invasive ductal carcinoma & 89 & \\
Invasive lobular carcinoma & 4 & \\
Invasive papillary carcinoma & 1 & \\
Medullary carcinoma, atypical & 1 & \\
Mucinous adenocarcinoma & 7 & \\
Non-invasive tumors & 4 & \\
Ductal CIS & 2 & \\
Intraductal papillary carcinoma & 2 &
\end{tabular}

Histological grade

Low (I and II)

97

High (III)

HER2/neu IHC

Negative $(0$ to +1$)$

56

Positive $(+2$ to +3$)$

$104^{\mathrm{b}}$

Lymph node metastasis

Negative

60

Positive

34

TNM staging

$100^{\mathrm{c}}$

\begin{tabular}{lcr} 
T1 $: 31$ & n0 $: 64$ & $\mathrm{~m} 0: 95$ \\
T2 $: 58$ & n1a $: 17$ & $\mathrm{~m} 1: 5$ \\
T3 $: 5$ & n2a $: 9$ & \\
T4 $: 3$ & n3a $: 10$ & \\
Tis $: 2$ & & \\
Tx $: 1$ & & \\
\hline
\end{tabular}

${ }^{\mathrm{a}}$ One case of medullary carcinoma, atypical was not analyzed, ${ }^{\mathrm{b}} \mathrm{One}$ case was not examined for lymph node metastasis, ${ }^{c}$ Five cases without TNM staging data. BCa, breast cancer; CIS, carcinoma in situ; IHC, immunohistochemistry.

into the low (grade I and II, n=97, 91.5\%) and high (grade III, $\mathrm{n}=8,8.5 \%$ ) grade groups. HER $2 /$ neu protein expression was negative $(0$ to +1$)$ in 56 specimens and positive in 49 ( +2 to +3 ). In TNM staging for tumor size or direct extent of the primary tumor, T2 stage $(n=58)$ predominated followed by the T1 stage $(n=31)$, T3 stage $(n=3)$, T4 stage $(n=3)$ and CIS (Tis, $n=2$ ). Regarding the spread to regional lymph nodes, tumor cells were absent from regional lymph nodes in 64 (N0) and regional lymph node metastasis was present in 36 (N1). For distant metastasis, samples were grouped into no distant metastasis $(n=95)$ and metastasis to distant organs $(n=5)$.

RNA extraction. Total RNA was prepared from paraffin-embedded breast cancerous or normal tissue using a PureLink FFPE Total RNA Isolation kit (Invitrogen-Life Technologies, Carlsbad, CA, USA). Deparaffination, purification and washing were conducted according to the manufacturer's instructions. RNA quality was determined by the ratio of OD260 vs OD280 $\mathrm{nm}$. The RNA concentration was deter- 
mined by detecting absorbance at $280 \mathrm{~nm}$ on a Tecan Infinite M200 multiscan spectrophotometer (Tecan Group, Bayonne, NJ, USA).

cDNA synthesis. First-strand cDNA synthesis was carried out using the ImProm-II Reverse Transcription system (Promega, Madison, WI, USA). Briefly, up to $1 \mu \mathrm{g}$ of total RNA was premixed with Oligo (dT) and random hexamers in a vial, then heated at $70^{\circ} \mathrm{C}$ for $5 \mathrm{~min}$ and chilled at $4^{\circ} \mathrm{C}$ for $5 \mathrm{~min}$ for pre-denaturation. Subsequently, $4 \mu \mathrm{l}$ ImProm-II $5 \mathrm{X}$ reaction buffer, $25 \mathrm{mM} \mathrm{MgCl}$, $1 \mu 110 \mathrm{mM}$ dNTP Mix, 20 units ribonuclease inhibitor and nuclease-free water were added to a $1.5 \mathrm{ml}$ eppendorf tube. Then, $1 \mu \mathrm{l}$ ImProm-II Reverse Transcriptase was added to a final volume of $15 \mu \mathrm{l}$ and incubated at $25^{\circ} \mathrm{C}$ for $5 \mathrm{~min}$ for primer annealing, $42^{\circ} \mathrm{C}$ for $60 \mathrm{~min}$ for synthesis, and $70^{\circ} \mathrm{C}$ for $15 \mathrm{~min}$ to inactivate the enzyme. The generated cDNA were stored at $-20^{\circ} \mathrm{C}$ for quantitative PCR (qPCR).

Quantitative PCR. A total of $106 \mathrm{BCa}$ tissues underwent qPCR. Detection of mRNA expression levels with respect to endogenous Bcl2L12 and Bcl2L12A was performed by EZtime 2X SYBR-Green Premix real-time PCR (Yeastern Biotech, Taipei, Taiwan). The thermal cycling program was carried out on an IQ5 Real-Time PCR Detection system (Bio-Rad, Hercules, CA, USA). The increase in fluorescence emission (Rn) was measured during PCR amplification, and the difference $(\Delta R n)$ between the fluorescence emission of the product and the baseline was calculated with IQ5 Optical System software (Bio-Rad) and plotted against the cycle number. Threshold cycle values were then calculated by determining the point at which the emitted fluorescence exceeded the threshold, determined as 10 -fold the standard deviation of the baseline of cycles 3-15 (16). The reaction mixture contained $10 \mathrm{ng}$ cDNA diluted in $2.5 \mu \mathrm{l}$ diethylpyrocarbonate-treated water (Applied Biosystems, Foster City, CA, USA), $12.5 \mu 1$ EZtime 2X SYBR-Green Premix PCR and $2 \mu \mathrm{l}$ gene-specific primers (final concentration: $50 \mathrm{nmol} / 1$ each), in a final reaction volume of $25 \mu \mathrm{l}$. The reaction conditions were set up as follows: For Bcl2L12 and Bcl2L2A: denaturation of the template and activation of DNA polymerase at $95^{\circ} \mathrm{C}$ for $10 \mathrm{~min}$, followed by 45 cycles of $95^{\circ} \mathrm{C}$ for $20 \mathrm{sec}$; for denaturation of the PCR products, $58^{\circ} \mathrm{C}$ for $1 \mathrm{~min}$ for primer annealing and $72^{\circ} \mathrm{C}$ for $15 \mathrm{sec}$ for extension. The conditions for $\beta$-actin were: denaturation of the template and activation of DNA polymerase at $95^{\circ} \mathrm{C}$ for $10 \mathrm{~min}$ followed by 45 cycles of $95^{\circ} \mathrm{C}$ for $10 \mathrm{sec}$ for denaturation of the PCR products, $58^{\circ} \mathrm{C}$ for $1 \mathrm{~min}$ for primer annealing and $55^{\circ} \mathrm{C}$ for $15 \mathrm{sec}$ for extension. Each RT-PCR experiment was performed in duplicate to evaluate data reproducibility. To distinguish the main PCR products from primer-dimers or other non-specific products, a melting curve analysis of the PCR products was generated after amplification by heating the reaction mixtures at $60-95^{\circ} \mathrm{C}$ with a heat ramping rate of $0.1^{\circ} \mathrm{C} / \mathrm{sec}$ while continuously acquiring fluorescence emission data (18). The melting temperatures (Tm) of the target genes and $\beta$-actin amplicons were expected to be 80 and $85^{\circ} \mathrm{C}$ respectively, whereas primer-dimers or other non-specific products were characterized by a much lower Tm (up to $75.0^{\circ} \mathrm{C}$ ). The calculations and validation of the comparative
CT $\left(2^{-\Delta \Delta \mathrm{CT}}\right)$ method were used for target gene mRNA quantification. The application of this method was based on the hypothesis that the PCR amplification efficiencies of the target and the reference genes were similar to each other and close to $100 \%$ (17). The prerequisites for the application of the $2^{-\Delta \Delta \mathrm{CT}}$ method were checked in a validation experiment, in which $\mathrm{CT}$ values of target genes and $\beta$-actin were measured in a dilution series of control cDNA over a $10^{6}$-fold range and then plotted against log cDNA dilution according to a previous study (18). RT-PCR efficiency (E\%) for amplification of each gene was calculated using the formula: $\mathrm{E} \%=[-1+10$ $(-1 / \alpha)] \times 100$, where $\alpha$ is the slope of the corresponding amplification plot (18). $\beta$-actin was used as a reference gene to normalize the PCRs for the amount of RNA added to the reverse transcription reactions. Normalized results were expressed in the ratio of target gene mRNA copies to $\beta$-actin mRNA copies $(\mathrm{c} / \mathrm{c})$. The results were the average of data from at least triplicate experiments and were shown as fold increase \pm SEM. All primer pairs with respect to Bcl2L12, Bcl2L12A and $\beta$-actin were designed using a web-based program provided by GeneScript.com. The primer pairs were qualified and demonstrated: i) High amplification efficiency ( $\geq 96 \%$ ) across a wide range of cDNA dilutions (see Fig. 3); ii) specific single products in dissociation curve analysis; and iii) Tm similar to those predicted by oligonucleotide software. The sequences of each primer pair were as follows: Bcl2L12 forward, 5'-GGTCCAA GAGCAGCTGAAAT-3' and Bcl2L12 and reverse, 5'-AGGCC AGCTTCTGGTTAATG-3'; Bcl2L12A forward, 5'-CCACCT AGGCCCAGCTACT-3' and Bcl2L12A and reverse, 5'-CGGA GATTTCAGCTGCTCTT-3'; $\beta$-actin forward, 5'-GACATC CGCAAAGACCTGTA-3', and $\beta$-actin reverse, 5'-GGAGCA ATGATCTTGATCTTCA-3'. The amplification strategy for Bcl2L12 and Bcl2L12A mRNA is shown in Fig. 1.

Statistical analysis. Statistical procedures were conducted using SPSS 22.0 statistical software (IBM). A Kruskal-Wallis test was applied to discriminate whether expression levels with respect to $\mathrm{Bcl} 2 \mathrm{~L} 12$ and $\mathrm{Bcl} 2 \mathrm{~L} 12 \mathrm{~A}$ mRNA were significantly different across different stage, grade and TNM staging breast cancer groups. The Stepwise and Enter methods, respectively, were used in linear regression to determine associated factors for Bcl2L12 and Bcl2L12A mRNA expression in total, TNBC and non-TNBC samples. The analyzed variables included diagnostic age, clinical diagnosis type, tumor size, number of metastastic lymph nodes, TNM staging, staging, Her 2 expression, ER status, PR status, histological grade, lymph node metastasis, invasive status, grade 3 , TNBC, Bcl2L12 mRNA and Bcl2L12A mRNA. The different expression levels of $\mathrm{Bcl} 2 \mathrm{~L} 12$ and $\mathrm{Bcl} 2 \mathrm{~L} 12 \mathrm{~A}$ in dichotomous groups were assessed using the independent sample Student's t-test. The linear regression formula and plot of $\mathrm{Bcl} 2 \mathrm{~L} 12$ against $\mathrm{Bcl} 2 \mathrm{~L} 12 \mathrm{~A}$ were estimated using SigmaPlot 12.0 (Systat Software, Inc., San Jose, CA, USA). $\mathrm{P}<0.05, \beta>0.14$ and $\mathrm{r}^{2}>0.14$ were considered statistically significant.

\section{Results}

Since the amplification efficiencies of the target (Bcl2L12 and $\mathrm{Bcl} 2 \mathrm{~L} 12 \mathrm{~A})$ and reference gene ( $\beta$-actin) were approximately 


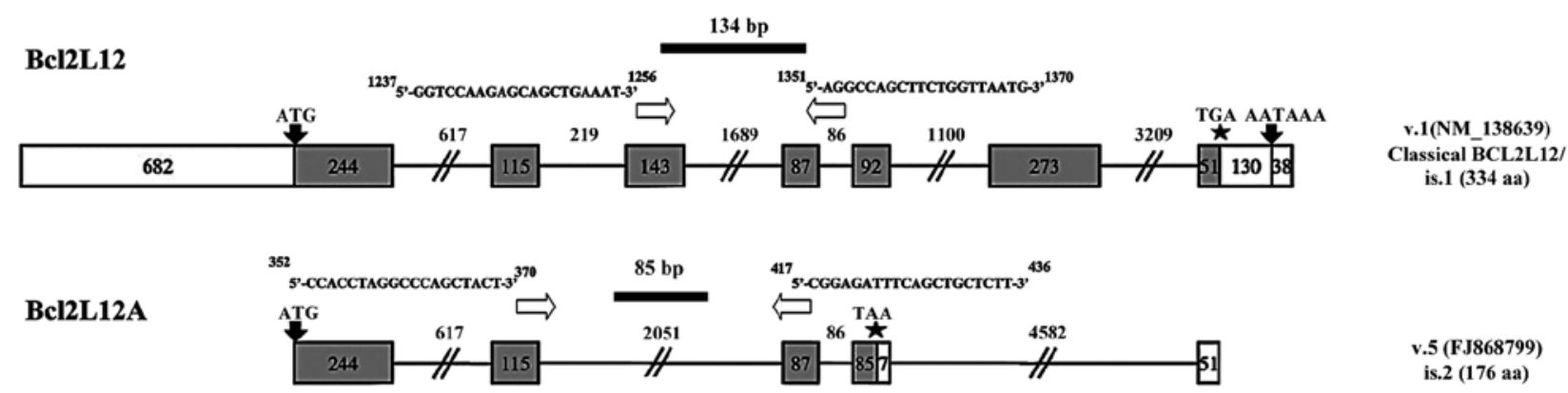

Figure 1. Bcl2L12 and Bcl2L12A amplification strategy in RT-PCR. The black lines are the amplicon of each gene. Empty arrows refer to the orientation of primer annealing.
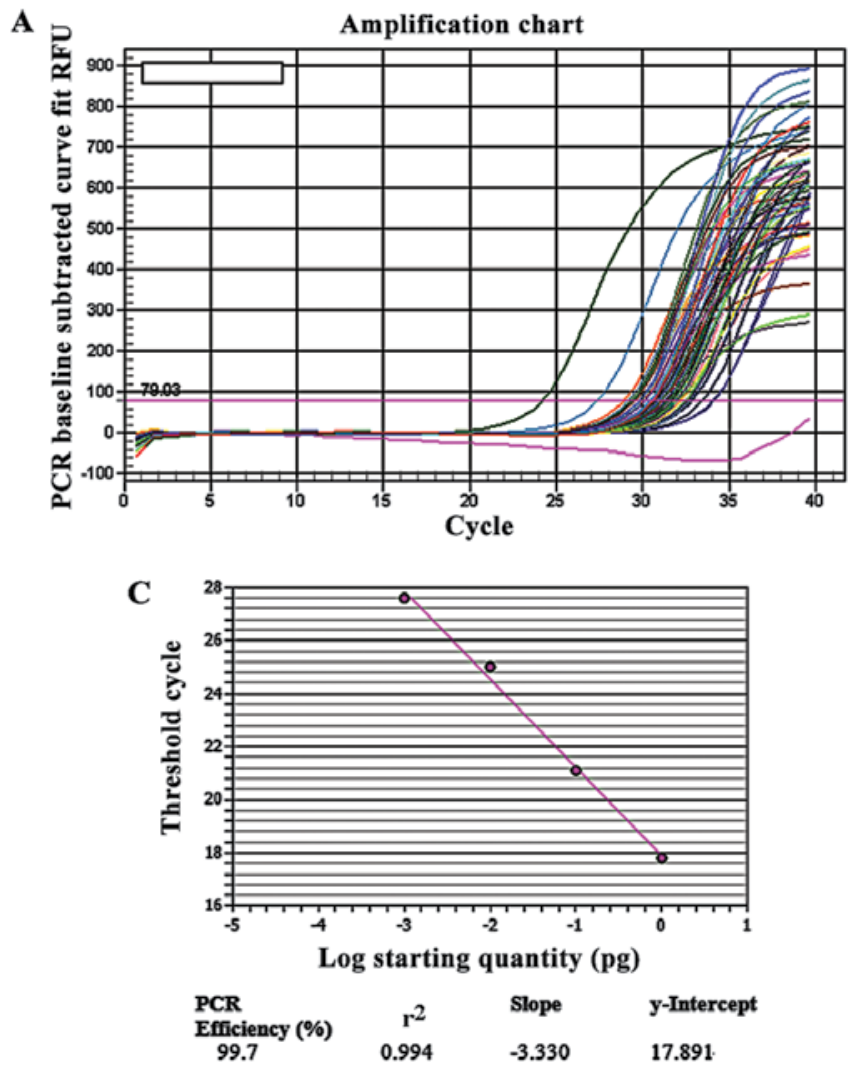

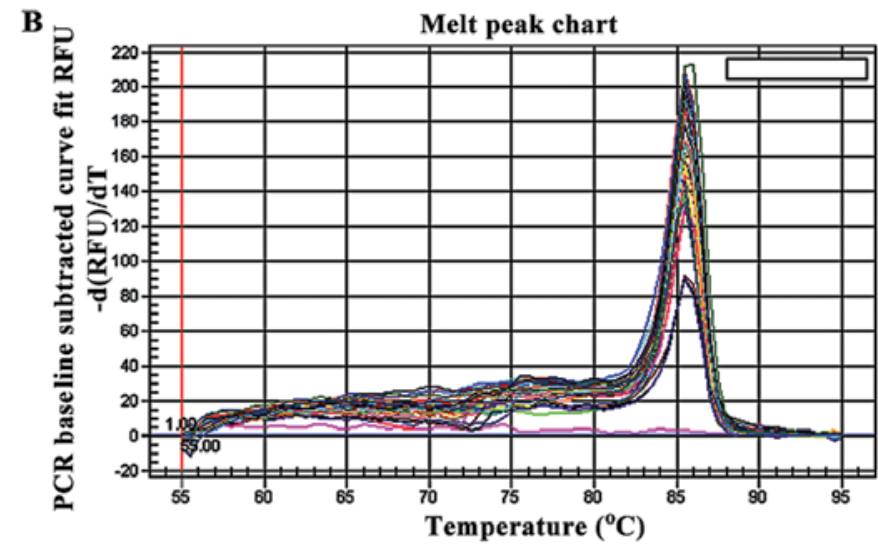

D $\quad \beta$-actin

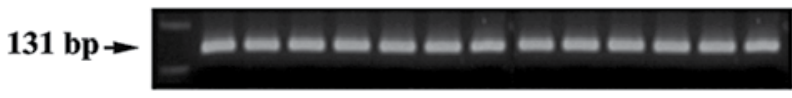

Bcl2L12

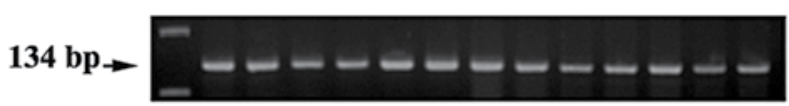

Bcl2L12A

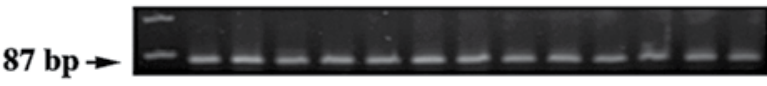

Figure 2. Amplification plot, melting curve analysis and standard curve of Bc12L12 quantitative PCR. (A) Amplification plot shows Bcl2L12 mRNA expression after baseline Rn signaling subtraction. (B) A single peak was detected in the melting curve analysis. (C) The standard curve of Bcl2L12. (D) Gel electrophoretic patterns for $\beta$-actin, Bcl2L12 and Bcl2L12A.

equal, the $\Delta \Delta \mathrm{Ct}$ calculations of our RT-PCR data were valid. The slopes of the Bcl2L12, Bcl2L12A and $\beta$-actin standard curves were similar $(-3.361,-3.341$ and -3.440 , respectively), and showed similar efficiencies to the corresponding amplicons $(98.4,99.0$ and $98.3 \%$, respectively). To confirm the efficient and specific amplification, the standard curve and melting curve analysis was generated for each target gene and the reference gene. As shown in Fig. 2, Bcl2L12 amplification showed a good amplification efficiency of 99.7 and $\mathrm{r}^{2}$ number of 0.994 of the standard curve. Checking the products by gel electrophoresis, the three target gene amplifications had the expected size bands as shown in Fig. 2D.

The expression levels with respect to Bcl2L12 and Bcl2L12A mRNA in our samples were estimated for the skew- ness value of 3.16-6.58 and kurtosis index of 9.38-44.828 (data not shown), suggesting that they were unlikely to be normally distributed. Therefore, a non-parametric statistical method, the Kruskal-Wallis test, was applied to discriminate whether expression levels with respect to Bcl2L12 and Bcl2L12A mRNA were significantly different across categories of stage, grade and TNM staging. As shown in Table II, there was no significant difference in the Bcl2L12 and Bcl2L12A mRNA expression for the categories of stage, grade and TNM staging $(\mathrm{P}>0.05)$. This result suggested that $\mathrm{Bcl} 2 \mathrm{~L} 2$ and $\mathrm{Bcl} 2 \mathrm{~L} 12 \mathrm{~A}$ mRNA expression were unlikely to be associated with $\mathrm{BCa}$ progression.

The correlation between Bcl2L12 and Bcl2L12A mRNA levels and clinicopathological characteristics was analyzed 
Table II. mRNA expression of Bcl2L12 and its variant in different BCa groups.

\begin{tabular}{|c|c|c|c|c|c|c|}
\hline Variables & Stage & No. & Mean rank & $\begin{array}{c}\text { Kruskal-Wallis } \\
\text { chi-square }\end{array}$ & df & Asymp. Sig. ${ }^{a}$ \\
\hline \multirow[t]{9}{*}{ Bcl2L12 } & 0 (CIS) & 3 & 89.33 & 12.959 & 7 & 0.073 \\
\hline & IA & 24 & 45.42 & & & \\
\hline & IIA & 37 & 47.00 & & & \\
\hline & IIB & 13 & 46.69 & & & \\
\hline & IIIA & 7 & 53.29 & & & \\
\hline & IIIC & 9 & 67.67 & & & \\
\hline & IV & 4 & 27.75 & & & \\
\hline & $\mathrm{V}$ & 1 & 54.00 & & & \\
\hline & Total & 98 & & & & \\
\hline \multirow[t]{10}{*}{$\mathrm{Bcl} 2 \mathrm{~L} 12 \mathrm{~A}$} & 0 (CIS) & 3 & 72.33 & 5.072 & 7 & 0.651 \\
\hline & IA & 24 & 48.79 & & & \\
\hline & IIA & 37 & 45.57 & & & \\
\hline & IIB & 13 & 47.62 & & & \\
\hline & IIIA & 7 & 51.43 & & & \\
\hline & IIIC & 9 & 50.44 & & & \\
\hline & IV & 4 & 69.50 & & & \\
\hline & $\mathrm{V}$ & 1 & 66.00 & & & \\
\hline & Total & 98 & & & & \\
\hline & Grade & $\mathrm{N}$ & Mean rank & $\begin{array}{c}\text { Kruskal-Wallis } \\
\text { chi-square }\end{array}$ & df & Asymp. Sig. ${ }^{a}$ \\
\hline \multirow[t]{4}{*}{ Bcl2L12 } & I & 5 & 44.80 & 0.561 & 2 & 0.756 \\
\hline & II & 90 & 52.82 & & & \\
\hline & III & 8 & 47.25 & & & \\
\hline & Total & 103 & & & & \\
\hline \multirow[t]{5}{*}{$\mathrm{Bcl} 2 \mathrm{~L} 12 \mathrm{~A}$} & I & 5 & 53.80 & 0.028 & 2 & 0.986 \\
\hline & II & 90 & 51.82 & & & \\
\hline & III & 8 & 52.88 & & & \\
\hline & Total & 103 & & & & \\
\hline & TNM & $\mathrm{N}$ & Mean rank & $\begin{array}{c}\text { Kruskal-Wallis } \\
\text { chi-square }\end{array}$ & df & Asymp. Sig. ${ }^{\mathrm{a}}$ \\
\hline \multirow[t]{17}{*}{$\operatorname{Bcl} 2 \mathrm{~L} 12$} & TONOMO & 3 & 87.67 & 16.616 & 15 & 0.342 \\
\hline & T1N0M0 & 24 & 44.79 & & & \\
\hline & T1N1M0 & 3 & 38.33 & & & \\
\hline & T1N2M0 & 1 & 11.00 & & & \\
\hline & T1N2M1 & 1 & 53.00 & & & \\
\hline & T1N3M0 & 1 & 67.00 & & & \\
\hline & T2N0M0 & 33 & 47.15 & & & \\
\hline & T2N1M0 & 10 & 48.10 & & & \\
\hline & T2N1M1 & 1 & 27.00 & & & \\
\hline & $\mathrm{T} 2 \mathrm{~N} 2 \mathrm{M} 0$ & 6 & 59.33 & & & \\
\hline & $\mathrm{T} 2 \mathrm{~N} 3 \mathrm{M} 0$ & 6 & 69.50 & & & \\
\hline & T2N3M1 & 1 & 34.00 & & & \\
\hline & T3N0M0 & 3 & 39.33 & & & \\
\hline & T3N1M0 & 1 & 38.00 & & & \\
\hline & T3N1M1 & 1 & 16.00 & & & \\
\hline & T3N3M0 & 1 & 29.00 & & & \\
\hline & Total & 96 & & & & \\
\hline \multirow[t]{3}{*}{ Bcl2L12A } & TONOMO & 3 & 72.00 & 12.588 & 15 & 0.634 \\
\hline & T1N0M0 & 24 & 48.63 & & & \\
\hline & T1N1M0 & 3 & 19.00 & & & \\
\hline
\end{tabular}


Table II. Continued. mRNA expression of Bcl2L12 and its variant in different BCa groups.

\begin{tabular}{|c|c|c|c|c|c|c|}
\hline Variables & Stage & No. & Mean rank & $\begin{array}{c}\text { Kruskal-Wallis } \\
\text { chi-square }\end{array}$ & df & Asymp. Sig. ${ }^{a}$ \\
\hline & T1N2M0 & 1 & 18.00 & & & \\
\hline & T1N2M1 & 1 & 66.00 & & & \\
\hline & T2NOMO & 33 & 48.88 & & & \\
\hline & T2N1M0 & 10 & 44.90 & & & \\
\hline & T2N1M1 & 1 & 75.00 & & & \\
\hline & $\mathrm{T} 2 \mathrm{~N} 2 \mathrm{M} 0$ & 6 & 56.50 & & & \\
\hline & $\mathrm{T} 2 \mathrm{~N} 3 \mathrm{M} 0$ & 6 & 46.67 & & & \\
\hline & $\mathrm{T} 2 \mathrm{~N} 3 \mathrm{M} 1$ & 1 & 53.00 & & & \\
\hline & T3N0M0 & 3 & 56.67 & & & \\
\hline & T3N1M0 & 1 & 11.00 & & & \\
\hline & T3N1M1 & 1 & 65.00 & & & \\
\hline & T3N3M0 & 1 & 60.00 & & & \\
\hline & Total & 96 & & & & \\
\hline
\end{tabular}

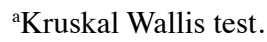

Table III. Parsimonious results of linear regression by stepwise method to identify the associated factors with respect to mRNA expression of Bcl2L12 and its variant.

\begin{tabular}{|c|c|c|c|c|c|c|c|c|}
\hline & & \multicolumn{2}{|c|}{$\begin{array}{l}\text { Unstandardized } \\
\text { coefficients }\end{array}$} & \multirow{2}{*}{$\frac{\begin{array}{c}\text { Standardized } \\
\text { coefficients }\end{array}}{\beta}$} & \multirow[b]{2}{*}{$\mathrm{t}$} & \multirow[b]{2}{*}{ Sig. } & \multicolumn{2}{|c|}{$95.0 \% \mathrm{CI}$ for B } \\
\hline \multicolumn{2}{|c|}{ Model factors } & $\mathrm{B}$ & Std. Error & & & & $\begin{array}{l}\text { Lower } \\
\text { bound }\end{array}$ & $\begin{array}{l}\text { Upper } \\
\text { bound }\end{array}$ \\
\hline \multirow[t]{4}{*}{1} & (Constant) & -98.068 & 155.768 & & -0.630 & 0.531 & -407.623 & 211.487 \\
\hline & Bcl2L12A mRNA & 0.103 & 0.027 & 0.356 & 3.782 & $<0.001$ & 0.049 & 0.157 \\
\hline & Grade 3 & 1060.372 & 485.531 & 0.205 & 2.184 & 0.032 & 95.481 & 2025.263 \\
\hline & TNBCa & 617.757 & 309.898 & 0.189 & 1.993 & 0.049 & 1.900 & 1233.614 \\
\hline \multirow[t]{2}{*}{2} & (Constant) & 80.170 & 35.256 & & 2.274 & 0.026 & 9.836 & 150.503 \\
\hline & Bcl2L12A mRNA & 0.037 & 0.008 & 0.473 & 4.465 & $<0.001$ & 0.021 & 0.054 \\
\hline \multirow[t]{2}{*}{3} & (Constant) & 1707.252 & 474.109 & & 3.601 & 0.001 & 765.351 & 2649.153 \\
\hline & Bcl2L12 mRNA & 1.327 & 0.336 & 0.385 & 3.953 & $<0.001$ & 0.660 & 1.995 \\
\hline \multirow[t]{4}{*}{4} & (Constant) & 3231.182 & 1084.556 & & 2.979 & 0.004 & 1066.399 & 5395.964 \\
\hline & $\mathrm{Bcl} 2 \mathrm{~L} 12 \mathrm{mRNA}$ & 4.865 & 1.236 & 0.384 & 3.936 & $<0.001$ & 2.398 & 7.332 \\
\hline & $\begin{array}{l}\text { Number of metastatic } \\
\text { lymph nodes }\end{array}$ & 381.132 & 88.158 & 0.505 & 4.323 & $<0.001$ & 205.168 & 557.095 \\
\hline & Staging & -142.309 & 51.131 & -0.324 & -2.783 & 0.007 & -244.367 & -40.250 \\
\hline
\end{tabular}

Models 1-2: Dependent variable is Bcl2L12 mRNA; models 3-4: Dependent variable is Bcl2L12A mRNA; models 1 and 3 denote total samples; models 2 and 4 denote non-TNBC group; Sig.: P-value. CI, confidence interval.

using linear regression. As shown in Table III, when the stepwise method was applied, the Bcl2L12 mRNA level was highly correlated with the Bcl2L12A mRNA level $(\beta=0.356$, $\mathrm{P}<0.001)$, grade 3 tumors $(\beta=0.205, \mathrm{P}=0.032)$ and $\mathrm{TNBC}$ status $(\beta=0.189, \mathrm{P}=0.049)$ in the total sample. However, grade 3 was no longer associated with a high $\mathrm{Bcl} 2 \mathrm{~L} 12$ mRNA expression in the total sample $(\beta=0.196, \mathrm{P}=0.229)$ when the Enter method was used (Table IV). Alternatively, $\mathrm{Bcl} 2 \mathrm{~L} 12$ was relevant to the number of metastatic lymph nodes $(\beta=0.837, P=0.030)$ and grade 3 tumors $(\beta=0.904$, $\mathrm{P}=0.016$ ) in the TNBC group (Table IV). Bcl2L12 mRNA was only correlated with Bcl2L12A mRNA expression in the non-TNBC group $(\beta=0.473, \mathrm{P}<0.001)$. Conversely, Bcl2L12A was solely associated with Bcl2L12 mRNA expression in the total sample (Table III, $\beta=0.385, \mathrm{P}<0.001)$ and was correlated with Bcl2L12 mRNA (Table III, $\beta=0.384, \mathrm{P}<0.001$ ), number of metastatic lymph nodes (Table III, $\beta=0.505, \mathrm{P}<0.001$ ) and staging (Table III, $\beta=-0.324, \mathrm{P}=0.007$ ) in the non-TNBC 
Table IV. Results of linear regression using the Enter method to identify the associated factors with respect to mRNA expression of Bcl2L12 and its variant.

\begin{tabular}{|c|c|c|c|c|c|c|c|c|}
\hline \multirow{2}{*}{\multicolumn{2}{|c|}{ Model factors }} & \multicolumn{2}{|c|}{$\begin{array}{l}\text { Unstandardized } \\
\text { Coefficients }\end{array}$} & \multirow{2}{*}{$\frac{\begin{array}{c}\text { Standardized } \\
\text { Coefficients }\end{array}}{\beta}$} & \multirow[b]{2}{*}{$\mathrm{t}$} & \multirow[b]{2}{*}{ Sig. } & \multicolumn{2}{|c|}{$95.0 \% \mathrm{CI}$ for $\mathrm{B}$} \\
\hline & & B & Std. Error & & & & $\begin{array}{l}\text { Lower } \\
\text { bound }\end{array}$ & $\begin{array}{l}\text { Upper } \\
\text { bound }\end{array}$ \\
\hline \multirow[t]{13}{*}{1} & (Constant) & 1201.310 & 2207.699 & & 0.544 & 0.588 & -3193.005 & 5595.625 \\
\hline & Bcl2L12A mRNA & 0.096 & 0.031 & 0.332 & 3.122 & 0.003 & 0.035 & 0.158 \\
\hline & TNBCa & 741.683 & 335.668 & 0.227 & 2.210 & 0.030 & 73.553 & 1409.813 \\
\hline & TNM staging & -.309 & 4.092 & -0.017 & -0.075 & 0.940 & -8.453 & 7.836 \\
\hline & Grade 3 & 1009.777 & 832.876 & 0.196 & 1.212 & 0.229 & -648.022 & 2667.575 \\
\hline & Staging & 8.852 & 26.723 & 0.057 & 0.331 & 0.741 & -44.338 & 62.042 \\
\hline & Histological grade & 455.355 & 627.208 & 0.120 & 0.726 & 0.470 & -793.071 & 1703.782 \\
\hline & $\begin{array}{l}\text { No. of metastatic } \\
\text { lymph nodes }\end{array}$ & 8.389 & 41.075 & 0.029 & 0.204 & 0.839 & -73.368 & 90.147 \\
\hline & Invasive & -1460.935 & 1134.381 & -0.346 & -1.288 & 0.202 & -3718.863 & 796.993 \\
\hline & Lymph node metastasis & 40.941 & 415.754 & 0.014 & 0.098 & 0.922 & -786.596 & 868.479 \\
\hline & Tumor size & -108.108 & 128.346 & -0.153 & -0.842 & 0.402 & -363.574 & 147.359 \\
\hline & Clinical diagnosis type & -193.893 & 313.043 & -0.178 & -0.619 & 0.537 & -816.990 & 429.203 \\
\hline & Diagnostic age & -8.884 & 11.252 & -0.083 & -0.789 & 0.432 & -31.281 & 13.514 \\
\hline \multirow[t]{13}{*}{2} & (Constant) & 6960.557 & 9841.433 & & 0.707 & 0.499 & -15733.829 & 29654.942 \\
\hline & Bcl2L12A mRNA & 0.077 & 0.090 & 0.194 & 0.850 & 0.420 & -0.131 & 0.285 \\
\hline & Diagnostic age & 36.151 & 44.194 & 0.203 & 0.818 & 0.437 & -65.761 & 138.063 \\
\hline & Clinical diagnosis type & -1822.850 & 1963.595 & -0.738 & -0.928 & 0.380 & -6350.909 & 2705.209 \\
\hline & Tumor size & -1478.243 & 645.415 & -1.366 & -2.290 & 0.051 & -2966.572 & 10.087 \\
\hline & $\begin{array}{l}\text { No. of metastatic } \\
\text { lymph nodes }\end{array}$ & 679.731 & 258.063 & 0.837 & 2.634 & 0.030 & 84.636 & 1274.825 \\
\hline & TNM staging & 38.209 & 19.514 & 1.120 & 1.958 & 0.086 & -6.789 & 83.208 \\
\hline & Staging & -123.668 & 96.783 & -0.436 & -1.278 & 0.237 & -346.851 & 99.514 \\
\hline & Her 2 expression & 2298.805 & 1374.020 & 0.362 & 1.673 & 0.133 & -869.692 & 5467.301 \\
\hline & Histological grade & 1078.154 & 1614.687 & 0.213 & 0.668 & 0.523 & -2645.320 & 4801.629 \\
\hline & Lymph node metastasis & -4828.536 & 2355.310 & -0.842 & -2.050 & 0.075 & -10259.890 & 602.818 \\
\hline & Invasive & -9889.988 & 6180.396 & -1.280 & -1.600 & 0.148 & -24142.006 & 4362.030 \\
\hline & Grade 3 & 6985.884 & 2306.121 & 0.904 & 3.029 & 0.016 & 1667.960 & 12303.808 \\
\hline \multirow[t]{13}{*}{3} & (Constant) & -415.603 & 601.281 & & -0.691 & 0.492 & -1620.114 & 788.909 \\
\hline & Bcl2L12A mRNA & 0.035 & 0.010 & 0.450 & 3.409 & 0.001 & 0.015 & 0.056 \\
\hline & Diagnostic age & 4.948 & 3.159 & 0.194 & 1.566 & 0.123 & -1.380 & 11.276 \\
\hline & Clinical diagnosis type & 110.386 & 77.675 & 0.476 & 1.421 & 0.161 & -45.215 & 265.987 \\
\hline & Tumor size & 68.108 & 34.841 & 0.382 & 1.955 & 0.056 & -1.687 & 137.903 \\
\hline & $\begin{array}{l}\text { No. of metastatic } \\
\text { lymph nodes }\end{array}$ & 3.603 & 10.436 & 0.061 & 0.345 & 0.731 & -17.304 & 24.509 \\
\hline & TNM staging & -1.482 & 1.025 & -0.352 & -1.447 & 0.154 & -3.535 & 0.570 \\
\hline & Staging & 5.746 & 7.202 & 0.166 & 0.798 & 0.428 & -8.681 & 20.172 \\
\hline & Her 2 expression & -85.187 & 73.381 & -0.141 & -1.161 & 0.251 & -232.186 & 61.812 \\
\hline & Histological grade & 53.824 & 94.210 & 0.090 & 0.571 & 0.570 & -134.902 & 242.550 \\
\hline & Lymph node metastasis & 21.775 & 33.721 & 0.088 & 0.646 & 0.521 & -45.777 & 89.326 \\
\hline & Invasive & -168.374 & 217.986 & -0.162 & -0.772 & 0.443 & -605.053 & 268.305 \\
\hline & Grade 3 & -57.712 & 99.344 & -0.092 & -0.581 & 0.564 & -256.722 & 141.298 \\
\hline \multirow[t]{5}{*}{4} & (Constant) & -13851.468 & 7453.258 & & -1.858 & 0.067 & -28686.807 & 983.872 \\
\hline & TNBCa & 1055.147 & 1184.807 & 0.094 & 0.891 & 0.376 & -1303.152 & 3413.446 \\
\hline & TNM staging & 17.390 & 13.950 & 0.271 & 1.247 & 0.216 & -10.377 & 45.158 \\
\hline & Grade 3 & -3106.166 & 2872.626 & -0.174 & -1.081 & 0.283 & -8823.986 & 2611.653 \\
\hline & Staging & -45.721 & 91.915 & -0.086 & -0.497 & 0.620 & -228.674 & 137.232 \\
\hline
\end{tabular}


Table IV. Continued. Results of linear regression using the Enter method to identify the associated factors with respect to mRNA expression of Bcl2L12 and its variant.

\begin{tabular}{|c|c|c|c|c|c|c|c|c|}
\hline \multirow{2}{*}{\multicolumn{2}{|c|}{ Model factors }} & \multicolumn{2}{|c|}{$\begin{array}{l}\text { Unstandardized } \\
\text { Coefficients }\end{array}$} & \multirow{2}{*}{$\begin{array}{c}\begin{array}{c}\text { Standardized } \\
\text { Coefficients }\end{array} \\
\beta\end{array}$} & \multirow[b]{2}{*}{$\mathrm{t}$} & \multirow[b]{2}{*}{ Sig. } & \multicolumn{2}{|c|}{$95.0 \% \mathrm{CI}$ for $\mathrm{B}$} \\
\hline & & B & Std. Error & & & & $\begin{array}{l}\text { Lower } \\
\text { bound }\end{array}$ & $\begin{array}{l}\text { Upper } \\
\text { bound }\end{array}$ \\
\hline & Histological grade & 2444.395 & 2148.886 & 0.187 & 1.138 & 0.259 & -1832.856 & 6721.646 \\
\hline & $\begin{array}{l}\text { No. of metastatic } \\
\text { lymph nodes }\end{array}$ & 328.809 & 136.518 & 0.328 & 2.409 & 0.018 & 57.077 & 600.542 \\
\hline & Invasive & 5633.146 & 3894.765 & 0.387 & 1.446 & 0.152 & -2119.189 & 13385.480 \\
\hline & Tumor size & -370.230 & 441.864 & -0.151 & -0.838 & 0.405 & -1249.738 & 509.278 \\
\hline & Clinical diagnosis type & 1825.681 & 1060.586 & 0.484 & 1.721 & 0.089 & -285.363 & 3936.725 \\
\hline & Diagnostic age & 41.296 & 38.611 & 0.112 & 1.070 & 0.288 & -35.558 & 118.150 \\
\hline & Bcl2L12 mRNA & 1.141 & 0.365 & 0.331 & 3.122 & 0.003 & 0.414 & 1.868 \\
\hline \multirow[t]{13}{*}{5} & (Constant) & -16618.637 & 37593.474 & & -0.442 & 0.670 & -103309.343 & 70072.069 \\
\hline & Diagnostic age & 137.144 & 165.604 & 0.305 & 0.828 & 0.432 & -244.740 & 519.029 \\
\hline & Clinical diagnosis type & -473.151 & 7749.804 & -0.076 & -0.061 & 0.953 & -18344.230 & 17397.928 \\
\hline & Tumor size & -2196.546 & 3016.639 & -0.803 & -0.728 & 0.487 & -9152.928 & 4759.836 \\
\hline & $\begin{array}{l}\text { No. of metastatic } \\
\text { lymph nodes }\end{array}$ & -473.285 & 1312.034 & -0.231 & -0.361 & 0.728 & -3498.840 & 2552.270 \\
\hline & TNM staging & 47.881 & 87.395 & 0.555 & 0.548 & 0.599 & -153.653 & 249.416 \\
\hline & Staging & 143.306 & 395.105 & 0.200 & 0.363 & 0.726 & -767.806 & 1054.419 \\
\hline & Her2 expression & -1857.754 & 5951.652 & -0.116 & -0.312 & 0.763 & -15582.287 & 11866.780 \\
\hline & Histological grade & 6187.159 & 5825.695 & 0.484 & 1.062 & 0.319 & -7246.917 & 19621.235 \\
\hline & Lymph node metastasis & -5737.446 & 10720.572 & -0.396 & -0.535 & 0.607 & -30459.130 & 18984.238 \\
\hline & Invasive & -1871.498 & 26626.121 & -0.096 & -0.070 & 0.946 & -63271.444 & 59528.448 \\
\hline & Grade 3 & -7020.365 & 12429.037 & -0.360 & -0.565 & 0.588 & -35681.777 & 21641.046 \\
\hline & Bcl2L12 mRNA & 1.079 & 1.270 & 0.427 & 0.850 & 0.420 & -1.849 & 4.008 \\
\hline \multirow[t]{15}{*}{6} & (Constant) & -1754.655 & 7050.335 & & -0.249 & 0.804 & -15878.173 & 12368.863 \\
\hline & Diagnostic age & -29.233 & 37.502 & -0.090 & -0.780 & 0.439 & -104.358 & 45.892 \\
\hline & Clinical diagnosis type & 654.643 & 919.482 & 0.223 & 0.712 & 0.479 & -1187.302 & 2496.587 \\
\hline & Tumor size & -179.240 & 419.998 & -0.079 & -0.427 & 0.671 & -1020.597 & 662.117 \\
\hline & $\begin{array}{l}\text { No. of metastatic } \\
\text { lymph nodes }\end{array}$ & 358.237 & 112.268 & 0.475 & 3.191 & 0.002 & 133.336 & 583.137 \\
\hline & TNM staging & 15.254 & 12.021 & 0.286 & 1.269 & 0.210 & -8.826 & 39.335 \\
\hline & Staging & -178.224 & 81.186 & -0.406 & -2.195 & 0.032 & -340.860 & -15.589 \\
\hline & Her2 expression & 585.023 & 863.977 & 0.077 & 0.677 & 0.501 & -1145.730 & 2315.776 \\
\hline & ER status & -634.557 & 1100.531 & -0.083 & -0.577 & 0.567 & -2839.186 & 1570.071 \\
\hline & PR status & 116.982 & 395.094 & 0.037 & 0.296 & 0.768 & -674.485 & 908.450 \\
\hline & Histological grade & 1196.637 & 2555.108 & 0.091 & 0.468 & 0.641 & -3921.859 & 6315.133 \\
\hline & Lymph metastasis & -920.613 & 1157.537 & -0.116 & -0.795 & 0.430 & -3239.437 & 1398.211 \\
\hline & Invasive & 2211.404 & 3558.910 & 0.184 & 0.621 & 0.537 & -4917.949 & 9340.756 \\
\hline & Grade 3 & 828.127 & 3043.055 & 0.050 & 0.272 & 0.787 & -5267.844 & 6924.098 \\
\hline & Bcl2L12 mRNA & 4.843 & 1.421 & 0.382 & 3.409 & 0.001 & 1.997 & 7.689 \\
\hline
\end{tabular}

Models 1-3: Dependent variable is Bcl2L12 mRNA; models 4-6: Dependent variable is Bcl2L12A mRNA; clinical diagnostic type indicates diagnostic BCa type; models 1 and 4 denote total samples; models 2 and 5 denote TNBC group; models 3 and 6 denote non-TNBC group. CI, confidence interval.

group when using the stepwise method. Nevertheless, when the Enter method was used, Bcl2L12A mRNA was additionally associated with the number of metastatic lymph nodes
(Table IV, $\beta=0.328, \mathrm{P}=0.018$ ) in the total sample and correlated with Bcl2L12 mRNA (Table IV, $\beta=0.382, \mathrm{P}=0.001$ ), number of metastatic lymph nodes (Table IV, $\beta=0.475$, 
Table V. The Student's t-test was used to discriminate the difference between dichotomous groups of BCa.

\begin{tabular}{|c|c|c|c|c|c|c|}
\hline Variables & Groups & $\mathrm{N}$ & Mean & Std. Error Mean & t-value & P-value \\
\hline \multirow[t]{2}{*}{ Bcl2L12 } & Non-TNBC & 79 & 157.3000 & 39.02000 & -2.487 & 0.014 \\
\hline & TNBC & 24 & 899.7200 & 531.58000 & & \\
\hline \multirow[t]{2}{*}{ Bcl2L12A } & Non-TNBC & 79 & 1665.8200 & 412.22000 & -1.371 & 0.174 \\
\hline & TNBC & 24 & 3104.3300 & 1346.37000 & & \\
\hline \multirow[t]{2}{*}{$\mathrm{Bcl} 2 \mathrm{~L} 12$} & Non-grade 3 & 97 & 245.6278 & 92.84499 & -2.203 & 0.030 \\
\hline & Grade 3 & 8 & 1280.0088 & 1250.11850 & & \\
\hline \multirow[t]{2}{*}{$\mathrm{Bcl} 2 \mathrm{~L} 12 \mathrm{~A}$} & Non-grade 3 & 97 & 1976.7996 & 468.62588 & -0.013 & 0.989 \\
\hline & Grade 3 & 8 & 1998.6525 & 882.57020 & & \\
\hline \multirow[t]{2}{*}{$\mathrm{Bcl} 2 \mathrm{~L} 12$} & $\geq 12$ metastatic lymph nodes & 6 & 264.4200 & 124.34000 & 0.989 & 0.326 \\
\hline & $<12$ metastatic lymph nodes & 65 & 342.9000 & 148.20000 & & \\
\hline \multirow[t]{2}{*}{$\mathrm{Bcl} 2 \mathrm{~L} 12 \mathrm{~A}$} & $\geq 12$ metastatic lymph nodes & 6 & 5230.9800 & 3212.87000 & 2.363 & 0.021 \\
\hline & $<12$ metastatic lymph nodes & 65 & 1484.1300 & 393.26000 & & \\
\hline \multirow[t]{2}{*}{$\mathrm{Bcl} 2 \mathrm{~L} 12$} & $\geq$ Stage IA & 73 & 147.7100 & 38.71000 & -2.654 & 0.010 \\
\hline & $<$ Stage IA & 2 & 795.8700 & 546.37000 & & \\
\hline \multirow[t]{2}{*}{$\mathrm{Bcl} 2 \mathrm{~L} 12 \mathrm{~A}$} & $\geq$ Stage IA & 73 & 1559.1700 & 397.70000 & -2.710 & 0.008 \\
\hline & $<$ Stage IA & 2 & 8538.6600 & 7461.89000 & & \\
\hline
\end{tabular}

Bold area denotes the results from analysis of the non-TNBC group.
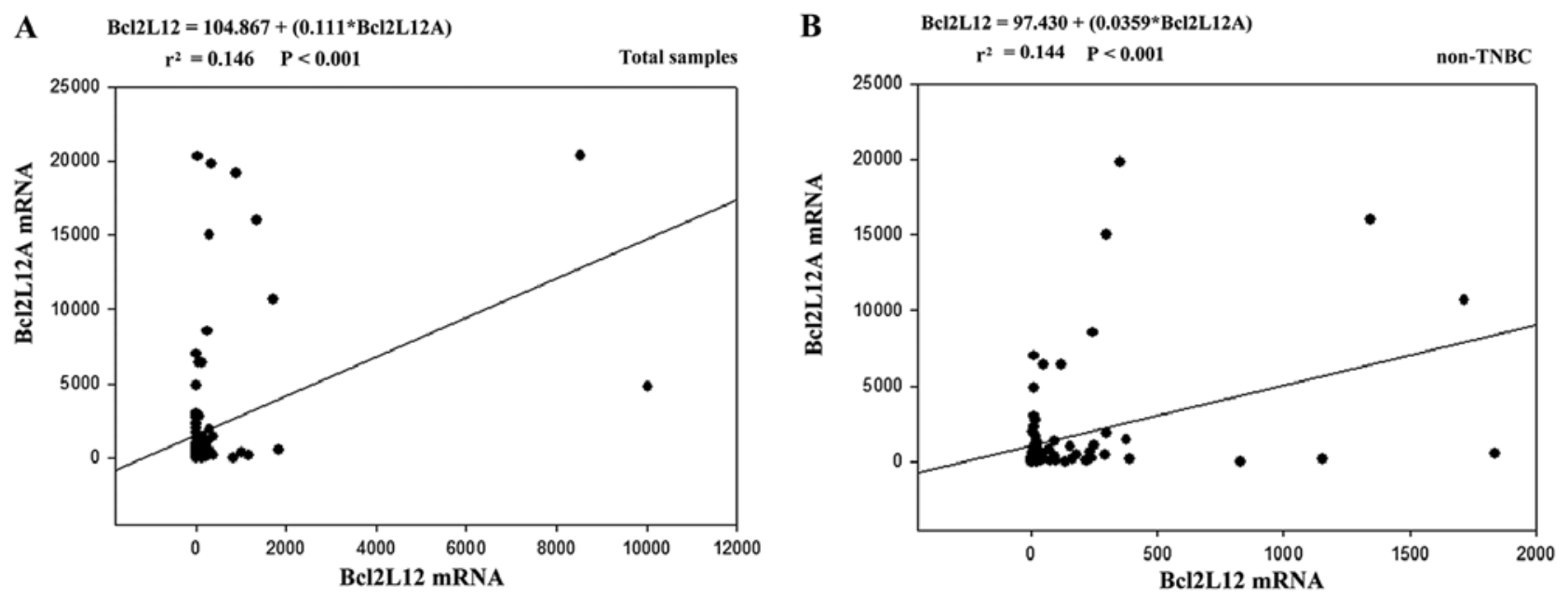

Figure 3. Regression plots of Bcl2L12 mRNA expression versus Bcl2L12A mRNA in total sample (A) or the non-TNBC group (B).

$\mathrm{P}=0.002$ ) and staging (Table IV, $\beta=-0.406, \mathrm{P}=0.032$ ) in the non-TNBC group, but not correlated with any analyzed variable in TNBC tumors (Table IV, $\mathrm{P}>0.05$ ). These results suggested that $\mathrm{Bcl} 2 \mathrm{~L} 12$ and $\mathrm{Bcl} 2 \mathrm{~L} 12 \mathrm{~A}$ have an unequal impact on TNBC and non-TNBC. Bcl2L12 has a unique role in TNBC, and a high expression correlated with high-grade tumor and the number of metastatic lymph nodes. Bcl2L12A was correlated with Bcl2L12 in non-TNBC and their association was possibly linked to the severity of lymph node metastasis. We assessed whether Bcl2L12 and/or Bcl2L12A were unequally expressed in the dichotomous group of $\mathrm{BCa}$. As a result, we observed that $\mathrm{Bcl} 2 \mathrm{~L} 12$, but not $\mathrm{Bc1} 2 \mathrm{~L} 12 \mathrm{~A}$, mRNA had a significantly higher expression in the TNBC than that in the non-TNBC group (Table $\mathrm{V}, \mathrm{P}=0.014$ ) and was also more highly expressed in grade 3 than non-grade
3 tumors (Table $\mathrm{V}, \mathrm{P}=0.030$ ). Conversely, in the non-TNBC group, tumors with metastatic lymph nodes $\geq 12$ were found to have a higher $\mathrm{Bcl} 2 \mathrm{~L} 12 \mathrm{~A}$ expression (Table $\mathrm{V}, \mathrm{P}=0.021$ ) than their counterparts. The CIS samples also showed a higher expression of $\mathrm{Bcl} 2 \mathrm{~L} 12$ and $\mathrm{Bcl} 2 \mathrm{~L} 12 \mathrm{~A}$ than other samples (Table V, Bcl2L12: $\mathrm{P}=0.010 ; \mathrm{Bcl} 2 \mathrm{~L} 12 \mathrm{~A}: \mathrm{P}=0.008$ ). Since, as mentioned above, Bcl2L12 was correlated with Bcl2L12A expression in the total sample and non-TNBC group, we plotted the regression line and estimated the regression formula as shown in Fig. 3 (total sample: Bcl2L12 $=104.867$ $+\left(0.111^{*} \mathrm{Bcl} 2 \mathrm{~L} 12 \mathrm{~A}\right)$; non-TNBC: $\mathrm{Bcl} 2 \mathrm{~L} 12=97.430+(0.0359 *$ $\mathrm{Bcl} 2 \mathrm{~L} 12 \mathrm{~A})$. According to the result and regression formula, Bcl2L12A mRNA expression had a 3-fold enhancement in the non-TNBC group compared to the total sample. In addition, Bcl2L12 was correlated with $\mathrm{Bcl} 2 \mathrm{~L} 12 \mathrm{~A}$ expression 
with a low level index $\left(\mathrm{r}^{2}=0.144-0.146, \mathrm{P}<0.001\right)$. These data indicated that the interplay between Bcl2L12 and its variant may be linked to non-TNBC tumors.

\section{Discussion}

In $\mathrm{BCa}, \mathrm{Bcl} 2 \mathrm{~L} 12$ expression is initially recognized as a good prognostic marker and is associated with long-term survival (19). Using a conventional RT-PCR approach, Bcl2L12 mRNA shows a relatively higher expression in low stage (I/II) and grade (I/II) tumors. The chemotherapeutic agent taxol, used to treat the MCF-7 BCa line, downregulates Bcl2L12A and caspase-9 expression, but causes elevation of Bax expression. Thomadaki et al (20) suggested that Bcl2L12 and $\mathrm{Bc} 12 \mathrm{~L} 12 \mathrm{~A}$ were potential biomarkers for predicting patient outcome after chemotherapy. Antineoplastic agents, such as cisplatin, carboplatin and doxorubicin have also been tested in different BCa lines. Bcl2L12 has been found to be associated with $\mathrm{BCa}$ chemoresistance associated with $\mathrm{Bcl} 2$ and can be modulated by chemotherapeutic drugs. The hypothesis of Bcl2L12 as a marker of favorable outcome in $\mathrm{BCa}$ is based on the finding that Bcl2L12 is highly expressed in low-stage clinical samples (8) and on acquired resistance to cisplatin consequent to RNAi-based knockdown of Bcl2L12 in the BCa MDA-MB-231 cancer cell line (7). Apparently, ectopically expressed GFP-tagged Bcl2L12 and Bcl2L12A inhibit $\mathrm{CHO}$ cell growth. However, Bcl2L12 is more likely to trigger apoptosis, whereas Bcl2L12A as a nuclear protein affects phosphorylation of cyclin B1 and interferes with the G2/M transition in the cell cycle to cause growth arrest (6). Investigation of the interaction of Bcl2L12 and its variant revealed that HSP70 protected Bcl2L12 and Bcl2L12A from $\mathrm{N}$-terminal ubiquitin-mediated proteosomal degradation (21). More recently, in contrast to previous findings on the role of $\mathrm{Bcl} 2 \mathrm{~L} 12$ in $\mathrm{BCa}$, a putative tumor suppressor of $\mathrm{BCa}, \mathrm{ER} \beta 5$, was found to interact with Bcl2L12, which may compete with the interaction of Bcl2L12-caspase-7 and result in sensitization to chemotherapeutic agent-induced apoptosis (15). This finding supports the anti-apoptotic role of Bcl2L12in GBM, by interacting with caspase-7 to antagonize apoptotic activity. Of note, the use of chemotherapeutic agents to treat cancer cell lines generally results in the downregulation of Bcl2L12 and activation of pro-apoptotic members in the $\mathrm{Bcl} 2$ protein family, such as Bax. Thus, the reason for chemotherapeutic agent-associated signaling downregulating a favorable prognosis marker such as Bcl2L12, should be investigated. However, Bcl2L12 and/or its variant may have different impacts on drug response, tumorigenesis and patient outcome. Bcl2L12 and Bcl2L12A need to be evaluated synchronously to elucidate their interplay in $\mathrm{BCa}$.

Regarding the correlation between ER and Bcl2L12, a previous study demonstrated that $\mathrm{Bcl} 2$ is more highly expressed in ER-positive and Bcl2L12-positive BCa (8). A high Bcl2L12 expression is suggested to be associated with ER and Bcl2 expression. However, in the present study, we observed that Bcl2L12 mRNA was more abundantly expressed in TNBC tumors. Furthermore, Bcl2L12A mRNA was elevated in TNBC compared to non-TNBC tumors although the result was not statistically significant. In non-TNBC, Bcl2L12A expression was markedly enhanced, correlated with Bcl2L12 mRNA level and was associated with the severity of lymph node metastasis. In another study, Bcl2L12 was found to interact with ERs through ER $\beta 5$, but not $E R \alpha, E R \beta 1$ and $\beta 2$ (15). The expression profiles of ER $\beta 5$, caspase-7 and Bcl2L12 in TNBC and non-TNBC subtypes should be further investigated.

Despite the lack of knowledge concerning the role of $\mathrm{Bcl} 2 \mathrm{~L} 12$ in $\mathrm{BCa}$, the molecular mechanism of $\mathrm{Bcl} 2 \mathrm{~L} 12$ involvement in GBM tumorigenesis is better known. Its caspase-inhibiting role is dependent on negatively regulating p53 transcription and the subsequent triggering of the $\alpha B$-crystallin/caspase-3 interaction $(22,23)$. Recent findings have demonstrated that $\alpha \mathrm{B}$-crystallin overexpression promoted brain metastasis, while silencing $\alpha \mathrm{B}$-crystallin inhibited brain metastasis in orthotopic TNBC (ER/PR/Her2 negative $\mathrm{BCa}$ (24). $\alpha \mathrm{B}$-crystallin promoted the adhesion of TNBC cells to HBMECs at least in part through an $\alpha 3 \beta 1$ integrin-dependent mechanism. These findings suggest a role for Bcl2L12 in TNBC brain metastasis. In the present study, we also found that TNBC highly expressed Bc12L12 and Bcl2L12A. In GBM, $\alpha \mathrm{B}$-crystallin is known to be a downstream gene of Bcl212 and may be important for inactivating caspase-3 during tumorigenesis. More studies are needed to determine whether Bcl2L12 is an upstream activator of $\alpha \mathrm{B}$-crystallin in promoting distal metastasis of TNBC. Thus, our results have shown that, a high Bcl2L12 and Bcl2L12A mRNA expression was not associated with $\mathrm{BCa}$ progression, but that Bcl2L12 mRNA was correlated with high-grade $\mathrm{BCa}$ and the TNBC subtype. In addition, the interplay between Bcl2L12 and its variant may be associated with high lymph node metastasis in non-TNBC tumors.

\section{Acknowledgements}

The authors would like to thank Gary Mawyer for language editing, the Department of Pathology of KAFGH for helping collect the tissue specimens and accessing the medical reviews and Dr Kao Wei-Tsung for providing the facilities and laboratory space to perform the molecular biology experiments. This study was supported by OPD research grant no. 102-29 from Kaohsiung Armed Forces General Hospital.

\section{References}

1. Anderson BO and Jakesz R: Breast cancer issues in developing countries: An overview of the Breast Health Global Initiative. World J Surg 32: 2578-2585, 2008.

2. Annual Reports of the Department of Health, the Executive Yuan, Republic of China (Taiwan), 2005.

3. Leong SP, Shen ZZ, Liu TJ, Agarwal G, Tajima T, Paik NS, Sandelin K, Derossis A, Cody H and Foulkes WD: Is breast cancer the same disease in Asian and Western countries? World J Surg 34: 2308-2324, 2010.

4. Foulkes WD, Smith IE and Reis-Filho JS: Triple-negative breast cancer. N Engl J Med 363: 1938-1948, 2010.

5. Scorilas A, Kyriakopoulou L, Yousef GM, Ashworth LK, Kwamie A and Diamandis EP: Molecular cloning, physical mapping, and expression analysis of a novel gene, BCL2L12, encoding a proline-rich protein with a highly conserved $\mathrm{BH} 2$ domain of the Bcl-2 family. Genomics 72: 217-221, 2001.

6. Hong Y, Yang J, Chi Y, Wang W, Wu W, Yun X, Kong X and $\mathrm{Gu}$ J: BCL2L12A localizes to the cell nucleus and induces growth inhibition through $\mathrm{G} 2 / \mathrm{M}$ arrest in $\mathrm{CHO}$ cells. Mol Cell Biochem 333: 323-330, 2010.

7. Hong Y, Yang J, Wu W, Wang W, Kong X, Wang Y, Yun X, Zong H, Wei Y, Zhang S, et al: Knockdown of BCL2L12 leads to cisplatin resistance in MDA-MB-231 breast cancer cells. Biochim Biophys Acta 1782: 649-657, 2008. 
8. Thomadaki H, Talieri M and Scorilas A: Prognostic value of the apoptosis related genes BCL2 and BCL2L12 in breast cancer. Cancer Lett 247: 48-55, 2007.

9. Florou D, Papadopoulos IN and Scorilas A: Molecular analysis and prognostic impact of the novel apoptotic gene BCL2L12 in gastric cancer. Biochem Biophys Res Commun 391: 214-218, 2010.

10. Stegh AH, Brennan C, Mahoney JA, Forloney KL, Jenq HT, Luciano JP, Protopopov A, Chin L and Depinho RA: Glioma oncoprotein Bcl2L12 inhibits the p53 tumor suppressor. Genes Dev 24: 2194-2204, 2010.

11. Stegh AH, Kesari S, Mahoney JE, Jenq HT, Forloney KL, Protopopov A, Louis DN, Chin L and DePinho RA: Bcl2L12-mediated inhibition of effector caspase-3 and caspase-7 via distinct mechanisms in glioblastoma. Proc Natl Acad Sci USA 105: 10703-10708, 2008

12. Stegh AH, Chin L, Louis DN and DePinho RA: What drives intense apoptosis resistance and propensity for necrosis in glioblastoma? A role for Bcl2L12 as a multifunctional cell death regulator. Cell Cycle 7: 2833-2839, 2008.

13. Stegh AH, Kim H, Bachoo RM, Forloney KL, Zhang J, Schulze H, Park K, Hannon GJ, Yuan J, Louis DN, et al: Bcl2L12 inhibits post-mitochondrial apoptosis signaling in glioblastoma. Genes Dev 21: 98-111, 2007.

14. Chou CH, Chou AK, Lin CC, Chen WJ, Wei CC, Yang MC, Hsu CM, Lung FW, Loh JK, Howng SL, et al: GSK3 $\beta$ regulates $\mathrm{Bcl} 2 \mathrm{~L} 12$ and Bcl2L12A anti-apoptosis signaling in glioblastoma and is inhibited by LiCl. Cell Cycle 11: 532-542, 2012

15. Lee MT, Ho SM, Tarapore P, Chung I and Leung YK: Estrogen receptor $\beta$ isoform 5 confers sensitivity of breast cancer cell lines to chemotherapeutic agent-induced apoptosis through interaction with Bcl2L12. Neoplasia 15: 1262-1271, 2013.

16. Giulietti A, Overbergh L, Valckx D, Decallonne B, Bouillon R and Mathieu C: An overview of real-time quantitative PCR Applications to quantify cytokine gene expression. Methods 25 : 386-401, 2001.
17. Livak KJ and Schmittgen TD: Analysis of relative gene expression data using real-time quantitative PCR and the 2[- $\Delta \Delta \mathrm{C}(\mathrm{T})]$ method. Methods 25: 402-408, 2001.

18. Fendri A, Kontos CK, Khabir A, Mokdad-Gargouri R and Scorilas A: BCL2L12 is a novel biomarker for the prediction of short-term relapse in nasopharyngeal carcinoma. Mol Med 17: 163-171, 2011.

19. Talieri M, Diamandis EP, Katsaros N, Gourgiotis D and Scorilas A: Expression of BCL2L12, a new member of apoptosis-related genes, in breast tumors. Thromb Haemost 89: 1081-1088, 2003.

20. Thomadaki H, Talieri M and Scorilas A: Treatment of MCF-7 cells with taxol and etoposide induces distinct alterations in the expression of apoptosis-related genes BCL2, BCL2L12, BAX CASPASE-9 and FAS. Biol Chem 387: 1081-1086, 2006.

21. Yang J, Hong Y, Wang W, Wu W, Chi Y, Zong H, Kong X, Wei Y, Yun X, Cheng C, et al: HSP70 protects BCL2L12 and BCL2L12A from N-terminal ubiquitination-mediated proteasomal degradation. FEBS Lett 583: 1409-1414, 2009.

22. Stegh AH, Kesari S, Mahoney JE, Jenq HT, Forloney KL, Protopopov A, Louis DN, Chin L and DePinho RA: Bcl2L12-mediated inhibition of effector caspase-3 and caspase-7 via distinct mechanisms in glioblastoma. Proc Natl Acad Sci USA 105: 10703-10708, 2008.

23. Stegh AH, Chin L, Louis DN and DePinho RA: What drives intense apoptosis resistance and propensity for necrosis in glioblastoma? A role for Bcl2L12 as a multifunctional cell death regulator. Cell Cycle 7: 2833-2839, 2008.

24. Malin D, Strekalova E, Petrovic V, Deal AM, Al Ahmad A Adamo B, Miller CR, Ugolkov A, Livasy C, Fritchie K, et al: $\alpha$-crystallin: a novel regulator of breast cancer metastasis to the brain. Clin Cancer Res 20: 56-67, 2014. 